\title{
Postverbal subjects in Romance and German: Some notes on the Unaccusative Hypothesis ${ }^{\text {th }}$
}

\author{
Andolin Egurkitza ${ }^{\mathrm{a}, *}$, Georg A. Kaiser ${ }^{\mathrm{b}}$ \\ a Filologia eta Geografi-Historia Fakultatea, Euskal Herriko Unibertsitatea, \\ Ubibertsitarearen ibilbideq 5, E-01006 Vitoria-Gasteiz, The Basque Country, Spain \\ b Romanisches Seminar, Universitüt Hamburg, \\ Von-Melle-Park 6, D-R0146, Hamburg, Germany
}

\begin{abstract}
This study deals with the problems presented by postverbal subjetcs in constructions with unaccusative verbs, because they apparently are counterexamples to the explanatory power of the Unaccusative Hypothesis. The paper defends the position that such cxamples do not weaken the hypothesis since it is assumed that such postverbal subjects ought to leave the original object position and move to a position where nominative case is regularly assigned. This account is supported by two kinds of consideration. On the one hand, there exists no inherent partitive case to justify the lack of movement, and on the other, agreement facts and distribution of expletive pronouns in different Romance languages and in German show that the postverbal position of subjects are not but the result of movements compatihle with the assignment of nominative case.
\end{abstract}

Keywords: Unaccusative Hypothesis; Postverbal subjects; Partitive; Expletive pronouns; Subject verb agreement; Inherent Case; Case assignment

\& We want to express our thanks to Regina Köppe, Christine Kossbiel, Jürgen M. Meisel, Natascha Müller, Giampaolo Salvi, Gesche Seemann, Achim Stenzel and Richard Waltereit for their helpful comments on earlier versions of this paper. Our special thanks go to the Alexander von Humboldt-Stiftung for the financial help provided to both authors. This help allowed both of them to spend a year of research at each other's universities, the University of Hamburg and the University of the Basque Country. We thank also all our informants, especially to Françoise Hasenclever, Werner Carigiet and Claudia Maissen. Finally, we would also like to thank Deanie Johnson and Simon Amos, who have helped us with the English, as well as the two anonymous Lingua reviewers for their insightful comments. We want also to express our thanks to the deceased Lingua editor, Teun Hoekstra, for his comments and support.

* Corresponding author. E-mail: fepegbia@vh.ehu.es 


\section{Introduction}

In this article we want to address the question of how to account for postverbal subject NPs in sentenecs with unaccusative verbs. Given the 'Unaccusative Hypothesis' (Perlmutter, 1978; Burzio, 1986), the occurrence of such postverbal NPs presents a problem since they should be raised to subject position in order to receive Case. Several proposals have been made in the literature in attempting to solve this problem (cf. Burzio, 1986; Belletti, 1988). In particular, we want to discuss the position of Belletti (1988), according to which the presence of postverbal NPs in these constructions is possible thanks to the assignment of an inherent Case, which she proposes to be partitive.

It is our contention to show that this position raises several problems, for both conceptual and empirical reasons. We will claim on the one hand that partitive is not a case, but a quantifier, and, on the other hand, we will provide data from several languages which disprove Belletti's assumption that these postverbal NPs are generally indefinite. Also, we will show that there is strong evidence to consider that these NPs are marked for Nominative Case, that is, the same Case which is assigned to subjects in preverbal position. In the case of morphological ergative languages, such as Basque, these NPs are assigned Absolutive Case.

In our proposal we will argue that this Case is neither assigned nor transmitted to the postverbal NP in its base position, since, according to the Unaccusative Hypothesis, Case assignment to that position is excluded. Therefore, in order to receive Case, the NP has to be raised to an appropriate position where its assignment is possible. This position is subject to cross-linguistic variation and, among others things, it depends on both the presence of a lexical expletive and on where the expletive is inserted. We want to defend that this proposal strengthens the explanatory power of the Unaccusative Hypothesis, as it explains why a surface subject is possible in a postverbal position with unaccusative verbs and passive constructions, even though these are not able to assign Case to it. In addition, our proposal accounts for some cross-linguistic differences with respect to the agreement patterns with unaccusative verbs and postverbal subjects which we attribute to differences in the way of how Case is assigned.

\section{Some properties of constructions with unaccusative verbs}

It is a well-known fact that intransitive verbs, which are characterized by the fact that they fail to have a direct object, do not form a homogeneous class, but must be divided in two subclasses. In the framework of Generative Grammar this is captured by the Unaccusative Hypothesis, which considers that one of theses classes has properties typical of transitive verbs (Perlmutter, 1978; Burzio, 1986). One crucial argument in favor of this distinction comes from Italian. It relies on the fact that the nominal head of a postverbal quantified NP in constructions with verbs like arrivare 'to arrive' or venire 'to come' can be replaced with the clitic proform ne, whereas verbs like telefonare 'to telephone' do not allow this kind of cliticization (Belletti and Rizzi, 1981; Burzio, 1986: 34): 
(1) a. Arriveranno molti esperti. will arrive many experts 'Many experts will arrive.'

b. $\mathrm{Ne}$ arriveranno molti. of-them will arrive many 'Many of them will arrive.'

(2) a. Telefoneranno molti esperti. will telephone many experts 'Many experts will telephone.'

b. ${ }^{*} \mathrm{Ne}$ telefoneranno molti. of-them will telephone many 'Many of them will telephone.'

Crucially, ne-cliticization is a property of quantified NP objects, i.e. the clitic ne is only used with objects but not with subjects:

(3) a. Gianni inviterà molti esperti. Gianni will invite many experts

b. Gianni ne inviterà molti. Gianni of-them will invite many 'Gianni will invite many of them.'

(4) a. Esamineranno il caso molti esperti. will examine the case many experts 'Many experts will examine the case.'

b. *Ne esamineranno il caso molti. of-them will examine the case many 'Many of them will examine the case.'

The contrasts in (1)-(4) show that NPs with verbs like arrivare in (1) behave like objects and not as subjects, as it happens with verbs like telefonare (cf. 2).

More evidence for these 'object' properties of surface subjects of verbs like arrivare can be found in other languages as well. In German, for example, it is possible in certain - semantically determined - cases to move the PP complement or adjunct of an object NP to the front of the clause (Grewendorf, 1989: 34f.):

(5) a. Der Großvater hat ein Buch über Boris Becker gelesen. the grandfather has a book about Boris Becker read 'The grandfather has read a book about Boris Becker.'

b. [Über Boris Becker $]_{i}$ hat der Großvater [ein Buch $e_{\mathrm{i}}$ ] gelesen. about Boris Becker has the grandfather a book read 'The grandfather has read a book about BORIS BECKER.'

What is relevant to our purpose here is that by means of this movement it is also possible to extract the PP complement or adjunct of an NP-subject in constructions with verbs like ankommen 'to arrive'. This extraction, however, produces ungram- 
matical results when the PP is inside the subject of a regular transitive verb, as shown by the contrast between (6) and (7) (Grewendorf, 1989: 35f.):

(6) a. Ein Buch über Boris Becker ist bei uns angekommen. a book about Boris Becker is at us arrived 'We have received a book about Boris Becker.'

b. [Über Boris Becker] ${ }_{i}$ ist [ein Buch $e_{i}$ ] bei uns angekommen. about Boris Becker is a book at us arrived 'We have received a book about BORIS BECKER.'

(7) a. Ein Buch über Boris Becker hat den Großvater begeistert. a book about Boris Becker has the grandfather excited 'A book about Boris Becker has excited the grandfather.'

b. *[Über Boris Becker $]_{\mathrm{i}}$ hat den Großvater [ein Buch $e_{\mathrm{i}}$ ] begeistert. about Boris Becker has the grandfather a book excited 'A book about BORIS BECKER has excited the grandfather.'

These facts among others can be taken as evidence for the assumption that verbs like arrivare in Italian or ankommen in German have some properties in common with transitive verbs since their subcategorized NPs behave like object NPs of transitive verbs. ${ }^{1}$ These are the facts that the Unaccusative Hypothesis tries to account for. According to it, the only NP subcategorized by intransitive verbs of the type of arrivare/ankommen is base-generated in object position. However, as opposed to regular transitive verbs, these verbs do not assign Case to their selected D-structure object, nor do they 0-mark the external argument position (Burzio, 1986):

(8)

$$
\begin{array}{lll} 
& \text { arrivare } & \frac{\mathrm{XP}}{[-\theta \text {-role }]} \\
{[+ \text { - Case }]} & & {[- \text { Case }]}
\end{array}
$$

So, it is therefore assumed that, instead of two classes, 'transitive' and 'intransitive' of traditional grammar, there are three classes of verb (Burzio, 1986: 30). However, despite the general acceptance of this distinction, there is a great confusion with respect to the terminology used to refer to it. Most linguists, especially those working in the generative framework, use either Permutter's or Burzio's terminology even though neither of them is quite satisfactory:

1 For further properties of these verbs, we refer the reader to Burzio (1986), Grewendorf (1989), Fanselow (1992), Levin and Rappaport Hovav (1995) and Herschensohn (1996). 
(9) Example

a. Giovanni esamina il caso Giovanni examines the case

b. Giovanni telefona Giovanni telephones

c. [e] arriva Giovanni arrives Giovanni
Perlmutter (1978) Burzio (1986)

transitive

transitive

unergative intransitive

unaccusative ergative

As it can be seen, both authors make reference to ergativity. But unfortunately, neither of them clarifies the reason why that term has been chosen. Burzio (1986: 73, fn. 11) only notes that the term ergative has often been used with verbs like Italian affondare 'to sink', because in addition to sentences like (10a), where it functions as intransitive, they have transitive counterparts like (10b):

(10) a. Due nave affondarono. two ships sank

b. L'artiglieria affondò due navi. the artillery sank two ships

But pretending that "we thus extend a more or less established use", Burzio (1986: 73 , fn. 11) uses the term ergativity to refer to verbs like arrivare as well. This, however, is completely misleading (cf. Wunderlich, 1985: 222, fn. 24). A look at Basque, a language with a typical ergative morphology, shall show this:
a. Bi untzi hondaratu dira. two ships-ABS sank
b. Artileriak bi untzi AUX artillery-ERG two ships-ABS sank
hondaratu ditu.
AUX

These parallel examples to those in (10) show that the subject of the intransitive verb in (11a), called 'ergative' by Burzio, is assigned Absolutive Case but no Ergative, while the subject of the verb in (11), a typical transitive verb, is assigned Ergative and its object Absolutive. In other words, his use of the term 'ergative' does not have any relationship whatsoever with its use in the grammar of languages with at least morphological ergativity.

Perlmutter (1978), on his part, doesn't give any reason either for his reference to ergative languages. Here too, a look at Basque shows that the use of the term unergative is misleading, for precisely with those verbs called unergatives by Perlmutter, even though they don't have any object, the subjects are marked ergative (Laka, 1993):
a. Irratiak ez du funtzionatzen. Radio-ERG not AUX functionning 'The radio doesn't function.'
b. Urak water-ERG boils 'The water boils.' diraki. 
Despite of this problem, we will be using Perlmutter's terminology, because it is more helpful than Burzio's, at least as nominative languages are concerned. As shown above, the term 'unaccusativity' refers to the fact that in these languages unaccusative verbs do not assign (accusative) Case to their object position. It results then that, in order to satisfy the Case Filter, any NP base-generated in that position has to move to the only place where Case is assigned, i.e. the position of the external argument:

$$
\begin{aligned}
& \text { [Una ragazza }]_{i} \text { è arrivata } t_{\mathrm{i}} \text {. } \\
& \text { a girl is arrived }
\end{aligned}
$$

This means that unaccusative verbs are analyzed exactly in the same way as passive verbs are:

(15) [Una ragazza $]_{i}$ è stata arrestata $t_{\mathrm{i}}$ dalla polizia. a girl is been arrested by-the police

(16) [Ein Mädchen $]_{\mathrm{i}}$ ist von der Polizei $t_{\mathrm{i}}$ verhaftet worden. a girl is by the police arrested been 'A girl was arrested by the police.'

In other words, this analysis provides a plausible explanation for the fact that in constructions with unaccusative verbs or with passive morphology the underlying object moves to the preverbal subject position where it is assigned Nominative Case. ${ }^{2}$

Yet, apparently, the raising of these D-structure objects to a preverbal position is not always obligatory. In Italian, for instance, in constructions with unaccusative and passive verbs the following sentences are grammatical:

(17) a. È arrivata una ragazza.

is arrived a girl

'A girl arrived.'

b. È stata arrestata una ragazza dalla polizia.

is been arrested a girl by-the police

'A girl was arrested by the police.'

2 That this Case is indeed Nominative becomes apparent if we pronominalize the NP una ragazza in (13) and (15):

(i) a. Lei è arrivata.

she [3ps, sg, fem, NOM] is arrived

h. *la è arrivata.

she [3ps, sg, fem, $\mathrm{ACC}]$ is arrived

(ii) a. $L e i$ è stata arrestata dalla polizia.

she [3ps, sg, fem, NOM] is been arrested by-the police

b. ${ }^{*} L a \quad$ è stata arrestata dalla polizia.

she $[3 \mathrm{ps}, \mathrm{sg}, \mathrm{fem}, \mathrm{ACC}]$ is been arrested by-the police 
In German, the corresponding sentences are also grammatical, but their acceptability is more restricted, since they generally appear in very marked contexts, i.e. in very literary or stereotyped texts:

(18) a. Es ist ein Mädchen angekommen.

it is a girl arrived

'A girl arrived.'

b. Es ist ein Mädchen von der Polizei verhaftet worden.

it is a girl by the police arrested been

'A girl was arrested by the police.'

The very same observation holds for French, for even though in spoken colloquial French this kind of sentence is almost completely excluded, it is usual in standard literary French:
a. Il est arrivé une fille.
it is arrived a girl
'A girl arrived.'
b. Il est arrêté une fille par la police.
it is arrested a girl by the police
'A girl was arrested by the police.'

These facts raise the problem of how to account for the Case assigned to the NP present in those constructions. In general, it has been assumed that Nominative Case may be assigned without movement of the postverbal subject NP. In most approaches this is implemented by means of Case Transmission (Chomsky, 1981, 1986; den Besten, 1985; Safir, 1985; Burzio, 1986; Vikner, 1995). Nominative Case is assigned to the preverbal non-argument subject and is then transmitted within a chain to the coindexed subject in object position. In some approaches, it has been suggested that Nominative is assigned directly, namely by $\mathrm{V}$, governing the NP in object position (cf. Pollock, 1983).

Note that all these proposals have in common that they allow Nominative Case assignment to the postverbal subject in its base position. Under the Unaccusative Hypothesis, this should not be true. Otherwise, as Belletti (1988: 18) correctly points out, "if nominative Case can be assigned to the object of an unaccusative verb, the whole explanatory capacity of [the unaccusative] hypothesis is lost". Belletti, therefore, rejects these analyses and proposes an alternative approach. This approach relies on the assumption that unaccusative verbs are able to assign an inherent Case, which she names partitive, to the D-structure NP in object position.

Belletti's 'Partitive proposal' has been widely accepted by the linguistic community, even though in our opinion there is no way to defend her position that there exists a case named partitive. In the following section we will try to show that this analysis also ought to be rejected for both conceptual and empirical reasons. In particular, the same argument that Belletti raises against the previous approaches holds for her own proposal, namely that it weakens the explanatory capacity of the Unac- 
cusative Hypothesis, according to which NPs generated in object position of unaccusative verbs must be moved since they are in a position in which neither structural nor inherent Case is assigned. Therefore, we will try to make a new proposal that does not depend on such an - in our opinion - incorrect assumption.

\section{Some problems with Belletti's approach}

As just mentioned, the crucial assumption in the approach provided by Belletti (1988) is that unaccusative verbs may assign Partitive Case to NPs in object position. Belletti claims that this is supported by the fact that postverbal NPs with unaccusative verbs are generally indefinite. In other words, she alleges, contrary to what is widely assumed (cf. Safir, 1985), that definiteness effect phenomena hold across languages and are not restricted to non-null subject languages. According to her data, in Italian a definite NP is allowed in constructions with unaccusative verbs like (20) only in a preverbal position (Belletti, 1988: 9f.):

(20) a. Il libro é stato messo sul tavolo
the book is been put on-the table
b. *E stato messo il libro sul tavolo.
is been put the book on-the table
'The book was put on the table.'

However, there appear certain cmpirical difficulties with the data provided by Belletti. First, some of the Italian data quoted by her in favor of the assumption that definiteness effects hold in sentences with unaccusative verbs are at least doubtful. Calabrese (1992: 120), for instance, states that some of the judgments given by Belletti for sentences like (21b) are not correct, since such sentences are at least 'marginally possible':

(21) a. All'improvviso è entrato un uomo dalla finestra. suddenly is entered a man from the window 'All of a sudden there entered a man through the window.' $\begin{array}{ll}\text { b. *All'improvviso è entrato } l \text { uomo dalla finestra. } \\ \text { suddenly } & \text { is entered the man from the window }\end{array}$

Second, in null subject languages other than Italian, like Spanish (22) and Portuguese (23), the definiteness effects assumed by Belletti do not hold:
a. De repente entró un hombre por la ventana. suddenly entered a man through the window
b. De repente entró el hombre por la ventana. suddenly entered the man through the window
(23) a. De repente entrou um homem pela janela. suddenly entered a man through the window 
b. ?De repente entrou $o$ homem pela janela.
suddenly entered the man through the window

Ambar (1992: 128), who provided the data in (23), notes that (23b) is perfectly grammatical when the NP is specified even further: ${ }^{3}$

(24)
De repente entrou $o$ homem do
chapéu preto pela
janela. suddenly entered the man with-the hat black through-the window 'All of a sudden the man with the black hat entered through the window.'

In this respect, we can also observe that non-null subject languages like English and French resemble Portuguese in that they do not seem to show definiteness effects, even though these sentences in the two languages are used only in a highly restricted style of language (Safir, 1985, for English; Le Bidois, 1952, for French):

(25) Suddenly entered the man with the black hat through the window.

(26) Soudain entra $l$ 'homme avec le chapeau noir par la fenêtre.

In German, too, the sentences corresponding to (21) are fully grammatical and common both with indefinite and definite postverbal NPs:

(27) a. Plötzlich ist ein Mann durch das Fenster eingestiegen.

b. Plötzlich ist der Mann durch das Fenster eingestiegen.

Belletti explains the facts in (27) by the 'verb-second' properties of German. In both sentences, the subjects, ein Mann and der Mann, can regularly move to the SpecIP position in order to receive Nominative Case. This movement, however, should be blocked in a sentence where an expletive is present, since this expletive, as proposed by Belletti, leaves a trace behind in SpecIP. ${ }^{4}$ According to this proposal, then, postverbal definite NPs should be excluded in German in those unaccusative constructions containing the expletive es. However, the alleged ungrammaticality of a sentence like (28) is at least questionable:

(28) ?Es liegt der Brief auf dem Tisch.

it lies the letter on the table

'The letter lies on the table.'

3 For similar judgments, see Duarte (1993) and Nascimento and Kato (1995).

4 It could be argued, as suggested by a Lingua reviewer, that Spanish and Portuguese, too, show verb second effects in sentences like (22) and (23) and that these languages differ from Italian in this respect. Note, however, that it is highly questionable whether these sentences are instances of verb second effects, given the fact that such adverb-initial sentences do not involve obligatory subject inversion in these languages (Torrego, 1984; Ambar, 1992; Kaiser, 1998). 
In fact, a suitable lexical choice or the addition of more linguistic material renders the appearance of a postverbal definite NP in such sentences completely acceptable (cf. Bayer, 1986; Grewendorf, 1989: 169; Vikner, 1995: 174, fn. 5): ${ }^{5}$

(29) a. Es liegt der Brief schon wieder auf dem Tisch.

it lies the letter already again on the table

'The letter is again on the table.'

b. Es liegt der Brief den ich dir gestern gezeigt habe schon it lies the letter that I you yesterday showed have already wieder auf dem Tisch. again on the table

'The letter I showed you yesterday is again on the table.'

Summarizing these empirical data, we may state that, in spite of some restrictions, both null subject and non-null subject languages allow postverbal definite NPs in unaccusative constructions. It may be true that in some non-null subject languages, like French or English, there exist more restrictions for the appearance of such NPs, but it is not true that these languages exclude them at all. This is in direct contrast with Belletti's claim that the definiteness effect is a (universal) property of NPs in object position of unaccusative verbs. In other words, we can state together with Grewendorf (1989: 170) that 'the question of whether an inverted subject occurs in definite or indefinite form has nothing to do with the way Case is assigned to the subject'. What is relevant for our purpose here is, that a hypothesis which is based on the existence of the definiteness effect does not hold (Brito, 1998).

Belletti's explanation relies on the observation that in Finnish indefinite NPs in postverbal position are morphologically marked with the so-called 'Partitive' Case (Belletti, 1988: 1):
a. Hän pani kiriat
pöydälle.
he put the books-ACC-pl on-the table
b. Hän pani kirjoja
pöydälle.
he put (some) books-PART-pl on-the table

This is similar to what happens in other morphologically rich languages, where 'partitiveness' is also expressed by means of a suffix, as is the case in Basque. In this

5 As already mentioned, we should add that one typically finds this type of sentence in literary texts, as well as in traditional songs, children's stories etc:

(i) a. Es ist ein Ros' entsprungen

it is a rose born

(Christmas carol)

b. Es rollten die Wellen und zerschellten am Riff

it rolled the waves and broke on-the reef

(Eva-Maria Hagen)

c. Es rattert durch die Innenstadt der blaue Autobus

it rattles through the downtown the blue bus

(James Krüss) 
language the partitive suffix $-i k$ may be used not only with D-structure objects of unaccusative verbs, but with objects in general, i.e. both with objects of unaccusative verbs (i.e., surface subjects) (31a) and objects of transitive verbs (31b):

(31)
a. Gizonik etorri da? man-PART come AUX 'Did any men come?'
b. Libururik irakurri duzu? book-PART read AUX 'Did you read any books?'

Moreover, partitive readings at least in Basque are also possible where this suffix is not present:
(32) Ogia jan dut. bread-ABS eaten AUX 'I ate (the) bread.'

In the absence of context, (32) is totally ambiguous, since it may mean both the bread and bread $^{6}$ As a matter of fact, if we translate into Basque the Finnish examples of (30), we also get the two readings even though no partitive suffix is present:
(33) Mahaiaren gainean liburuak jarri ditu. table-sg-GEN on book-pl-ABS put AUX 'S/he put the books/books on the table.'

In other words, one must assume that the Case assigned in sentences like (32) and (33) is not Partitive, but Absolutive, i.e., the case corresponding to objects of transitive verbs and subjects of intransitives/unaccusatives in morphologically ergative languages, which in Basque happens to be morphologically zero. In turn, this explains why the marker of partitive may appear only in those cases, i.e., precisely in those cases where the case marker is zero. ${ }^{7}$

6 In fact, (32) can be the answer to the following questions, (ia) with Partitive and (ib) without it:
(i) a. Ogirik jan duzu?
'Did you eat bread?'
b. Ogia jan duzu?
bread-ABS eaten AUX
'Did you eat the bread?'

7 Vikner (1995: 174f.) argues in the same way with respect to a morphologically rich language like German: "[...] we may ask the question of how partitive is morphologically realized in the languages where it is not an independent morphological case. We would then have to say that partitive shows up as nominative in German [...]. If partitive is realised as nominative in German, we are faced with a problem, because nominative is not possible in all the cases where Belletti predicts partitive to be possible". 
Grewendorf (1989: 172) also states that "a Case like the genitivus partitivus in German or Latin - which also expresses the idea of 'partitivity' - is not linked with any sort of definiteness effect [...]" (cf. 34a-34b). A similar observation can be made concerning Basque (cf. 34c):
a. Zwei meiner Fehler ...
two my-GEN mistakes
'Two of my mistakes ...'
b. Tertius regum romanorum ...
third-NOM kings-GEN Romans-GEN
'The third of the Roman kings ...'
c. Liburu zaharretarik bi ...
book old-PART two-ABS
'Two of the old books ...'

Given these facts, de Rijk (1972) and Ortiz de Urbina (1989: 97-108) analyze 'partitive' not as a case, ${ }^{8}$ but as an empty 'any-type'-quantifier (Hornstein, 1984), i.e., as a quantifier that does not move and must be therefore lexically governed. This explains the distribution of partitive. ${ }^{9}$ Also, both de Rijk and Ortiz de Urbina point out the similarity between Basque partitives, the Russian genitive of negation and the beaucoup de-constructions of French.

There are further problems with Belletti's proposal concerning the mechanisms of partitive assignment. Remember that her analysis covers verbs which lack "the capacity to assign structural accusative Case" (Belletti, 1988: 3). But in her theory, partitive assignment depends not only on the nature of the verb, but also on the position and the nature of the NP to which partitive is to be assigned.

Concerning the position of the NP, she argues that only those indefinite NPs that remain in the object position of unaccusative verbs receive Partitive Case, as in (17a), (18a) and (19a). In those constructions with unaccusative verbs, where an indefinite NP appears in subject position, as in (13) and (14), it is not assigned Partitive Case, but Nominative. In other words, an NP with the same partitive reading receives different Cases (Nominative or Partitive) according to the position in which it appears, i.e., subject or object position. To put it in another way, for Belletti the

8 See also Vikner (1995: 175) who argues in the same manner in his discussion of Belletti's approach. According to him, too, "partitive is not a specific case at all, but merely a way of licensing NPs, whose case is assigned/transferred in some other manner".

9 As a matter of fact, as it seems to be true for Finnish as well, Basque grammarians have always spoken of 'Partitive Case'. This is not the only exception though. For instance, in the grammar of Basque there also exist a number of postpositions that tradionally have been considered to be cases of the socalled Basque declension. The reason for this is that they are expressed by means of suffixes that cannot stand alone:

(i) etxetik

house-from

'from the house'

(ii) *0-tik

from 
appearance of partitive readings is dependent on the assignment of Partitive Case, but we have seen that such readings also may appear in (13) and (14), i.e., in situations in which Case is not, in her terms, Partitive but Nominative. One could save Belletti's position by saying that partitive is only assigned to unspecific indefinites. There is a fundamental difference between the indefinites in (13) or (14), which are specific, and those in (17a), (18a), which are not. Although this way of Case assignment would explain why the movement of an indefinite NP should or should not take place with unaccusative verbs, it does not resolve the fundamental problem that the assignement of Partitive as an inherent Case is made dependent on the nature of that NP.

In addition, even though Belletti mentions both (20a) and (20b), she cannot escape the facts of (35), i.e., that under certain circumstances the occurrence of a postverbal definite NP in constructions with unaccusative verbs is perfectly acceptable in Italian:

$$
\begin{aligned}
& \text { E arrivata la ragazza. } \\
& \text { is arrived-fem the girl }
\end{aligned}
$$

'The girl arrived'

According to Belletti's argumentation, la ragazza in (35) is not assigned Partitive Case due to its definiteness. What this means, then, is that the capability of assigning Partitive is not, in her proposal, a property of the subcategorization frame of the verb, but is a result of definiteness, which is, as noted by Grewendorf (1989: 171), "the sole criterion for the realization of partitive assignment, a consequence which makes Belletti's theory appear anything but well founded". As a matter of fact, Belletti saves her analysis by adopting the standard analysis for sentences like (35), where she supposes (35) to be an instance of 'free inversion'. Thus, she suggests that the NP la ragazza in (35) is moved to a VP-adjoined position where it is assigned Nominative Case directly by the governing category INFL (cf. Belletti, 1988: 21): ${ }^{10}$

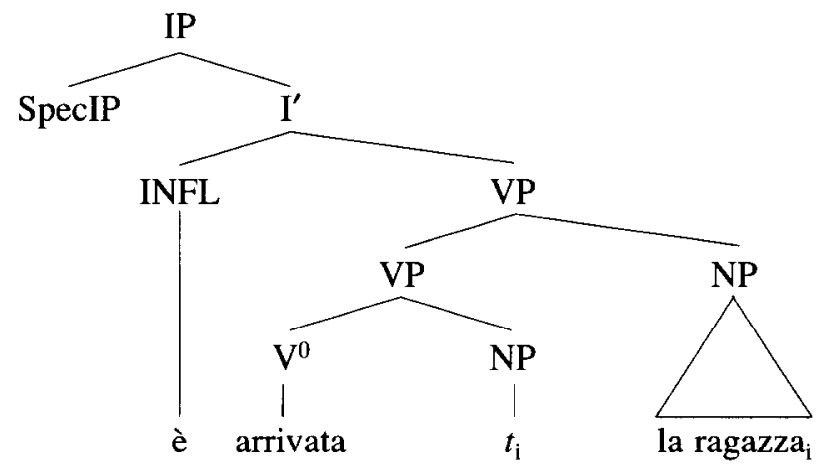

\footnotetext{
10 According to Belletti (1988: 9) the difference between (35) and (20b) is that in (20b) "the relevant postverbal NP is in the $\mathrm{NP}_{2}$ object position", whereas in (35) it is VP-adjoined.
} 
To sum up, in this section we have provided emprirical data which are not compatible with Belletti's account for postverbal subjects of unaccusative verbs. In addition, we have argued against the assumption that allows Partitive Case assignment in these constructions and also defended that Partitive Case does not exist.

\section{An alternative approach}

In this section we want to make a proposal that does not depart from the Unaccusative Hypothesis, but at the same time accounts for the fact that postverbal subjects of unaccusative verbs do receive Nominative Case as expected. It is our contention to show that the Unaccusative Hypothesis makes the correct prediction, namely that Case assignment to the position where these NPs originate is excluded. Therefore, these NPs are obliged to raise to an appropriate position in search of Case. In the following discussion we will show that the choice of the landing site is language specific. In other words, we claim that languages differ in the landing position of the subject NP which - as predicted by the Unaccusative Hypothesis - has to be raised in order to receive Case. We claim furthermore that the differences with respect to agreement phenomena with this type of verb are in direct correlation with the landing position of the subject NP.

\subsection{Nominative Case and subject verb agreement}

Consider first the following sentences from German, Spanish and Italian:

(37) a. Es sind drei Mädchen angekommen.

b. *Es ist drei Mädchen angekommen.

(38) a. Han llegado tres chicas.

b. ${ }^{*} \mathrm{Ha}$ llegado tres chicas.

(39) a. Sono arrivate tre ragazze.

b. ${ }^{*} E$ arrivata/o tre ragazze.

As can be observed, in all of the cases above, the postverbal NP must agree with the finite verb in person and number. As this is the same agreement that would obtain if the NP were in the standard subject position, we may feel safe in claiming that we are dealing with Nominative marked NPs. As matter of fact, in a morphologically rich language like German, we may see that the corresponding NPs receive Nominative:

(40) Es ist ein langer Brief angekommen.

it is a long letter-NOM arrived

'There arrived a long letter.'

The same can be observed in Romance when the postverbal subject is expressed by means of a pronoun, for instance, in Spanish: 
(41)
a. Han llegado ellas,
no ellos.
have arrived they-fem-NOM
not they-mas-NOM
b. *Han
llegado
las, no los.
have arrived them-fem-ACC
not them-mas-ACC
c. ${ }^{*}$ Las han llegado, no ellos.

Since we have excluded, on the basis of the Unaccusative Hypothesis, any Case assignment to the subject of an unaccusative verb in its base position, the question now is how to account for the assignment of Case to this postverbal NP. The answer is straightforward: by means of its raising to a position where Nominative Case can be assigned. In other words, we propose an analysis which does not consider these cases to be exceptions to the rule.

As for Spanish and Italian, we will adopt a free inversion analysis for sentences like (38a) and (39a), an analysis where the subject NP is moved to the right. Following Rizzi (1982: 132f.), we assume that in these constructions the inverted NP is moved to a VP-adjoined position and Case-marked by Case transmission via a chain with a 'dummy pronoun' in subject position:

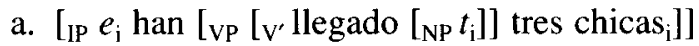
b. $\left[{ }_{\mathrm{IP}} e_{\mathrm{i}}\right.$ sono $\left[\mathrm{VP}\left[\mathrm{V}^{\prime}\right.\right.$ arrivate $\left.\left[{ }_{\mathrm{NP}} t_{\mathrm{i}}\right]\right]$ tre raggazze $\left.\left.\mathrm{i}_{\mathrm{i}}\right]\right]$

Note that, contrary to what is assumed by Belletti (1988), we do not distinguish here between unaccusatives with definite postverbal subjects and those with indefinite ones, whether specific or unspecific. In our approach, both constructions are considered to be the result of the same kind of inversion, namely free inversion.

As for German unaccusative constructions like (37a), we assume that the postverbal subject receives Nominative Case in the position where this Case normally is assigned. Thus, the postverbal NP in (a) is moved to the standard subject position, SpecIP or, more precisely, SpecAgrS:

\section{$\left[{ }_{\mathrm{CP}} \operatorname{Es~sind~}_{\mathrm{j}}\left[_{\mathrm{IP}}\right.\right.$ drei Mädchen ${ }_{\mathrm{i}}\left[{ }_{\mathrm{VP}}\left[{ }_{\mathrm{V}^{\prime}}\left[{ }_{\mathrm{NP}} t_{\mathrm{i}}\right]\right.\right.$ angekommen $\left.\left.\left.]\right] \mathbf{t}_{\mathrm{j}}\right]\right]$}

According to standard analyses of German, if the subject appears clause-initially it means that it has further moved to SpecCP (den Besten, 1983; Haider, 1986; Platzack and Holmberg, 1989). This movement is related to the verb-second properties of German which imply not only an obligatory V-to-COMP-movement, but also that SpecCP position must be necessarily filled (Gärtner and Steinbach, 1994; Schwartz and Vikner, 1996). In (37a), however, the movement of NP to SpecCP is blocked, apparently because of the presence of the expletive pronoun es. Thus, we only need to make the assumption that in this kind of construction expletives are inserted in their surface position as a mere stylistic option in which the subject of the sentence loses its topic function. In fact, this idea that the expletive is 'inserted' in its surface position is not new. It has been defended, for example, by Breckenridge 
(1975), Lenerz (1985), Tomaselli (1986), and Grewendorf (1989) due to the complementary distribution one finds in German between expletives and preverbal subjects:

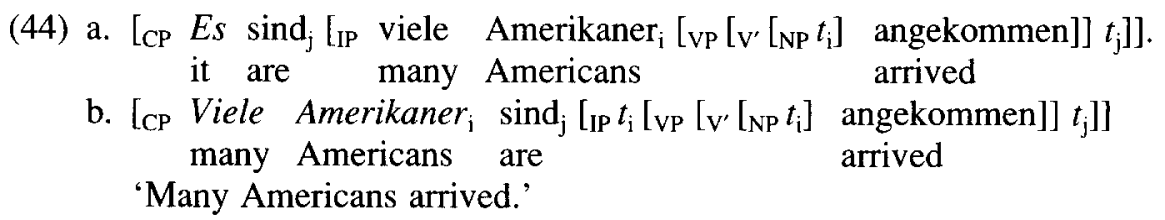

Note also that the same thing happens when the SpecCP position is occupied by an element other than expletive es. More importantly, in this case, the presence of the expletive is excluded, thus providing evidence for our proposal of expletive insertion in SpecCP:

(45) a. Gestern sind viele Amerikaner angekommen. yesterday are many Americans arrived 'Many Americans arrived yesterday.'

b. *Gestern sind es viele Amerikaner angekommen. yesterday are it many Americans arrived

(46) a. Warum sind viele Amerikaner angekommen? why are many Americans arrived 'Why did many Americans arrive?'

b. *Warum sind es viele Amerikaner angekommen? why are it many Americans arrived

Given these contrasts, and the fact that German is a verb-second language, i.e., a language in which $\mathrm{C}^{0}$ must always be lexically instantiated, the assumption that the expletive pronoun es is inserted in SpecCP accounts by itself for the fact that postverbal subjects receive Nominative Case. In other words, what is important to note in a sentence like (37a) is that German is a verb-second language, where the subject ends up in SpecAgrSP when SpecCP is filled with lexical material. ${ }^{11}$

At this point we are able to account rather naturally for the fact that in this language the finite verb always agrees with the postverbal subject rather than with the expletive. In our view, this is captured under the assumption that 'subject verb agree-

11 By making this proposal we are not giving an answer to the scrambling facts in German, where the subject may appear separated from the finite verb in COMP by a host of different material. Consider the following example, provided by one of the reviewers:

(i) Es sind dir gestern doch durch verschiedene Leute einige Bücher gezeigt worden. it are to-yon yesterday yet by several people some books shown been

'Yet yesterday some books have been shown to you by several people.'

Note however that the fact that the subject in (i) may appear in that position does not exclude our proposal for Nominative Case assignment, for as defended by Schwartz and Vikner (1996), all that material may be inserted by adjunctions to IP. In any case, we are not going into the question of scrambling in German. 
ment' is a reflex of Nominative Case assignment under specifier-head agreement within AgrSP.

In fact, this is the assumption we also want to make for the agreement patterns in Spanish and Italian. As already mentioned above, in the corresponding constructions in Spanish and Italian Nominative is transmitted through a chain to the postverbal subject NP. Nominative Case is assigned under agreement within AgrSP by the verbal head to an empty pronoun in SpecAgrSP and then transmitted to the postverbal subject within a chain. Given this chain, it becomes evident why the postverbal subject, being coindexed with a 'dummy' pronoun in SpecAgrSP, agrees in these constructions with the finite verb located in $\mathrm{AgrS}^{0}$.

However, note that, unlike in Spanish and Italian, in German the expletive pronoun is lexically overt in constructions such as (37a). Given our assumption that this expletive is inserted in SpecCP, we are confronted with the problem that this is a position where no Case assignment occurs. This is in direct opposition to the requirements of the the Case Filter, according to which every lexical NP ought to be Casemarked. An option to avoid this problem could be to assume that expletive es with German unaccusatives is generated in SpecAgrSP rather than in SpecCP. Then, Case would be assigned to the expletive before it moves to SpecCP. This proposal, which is defended by Belletti (1988), Cardinaletti (1990) and Vikner (1995), however, does not go through. First, it does not account for the complementary distribution which exists between expletive and other lexical elements in clause-initial position in German, and second, it excludes Nominative assignment to the postverbal subject, i.e., it requires a chain formation with the expletive for Nominative assignment, a mechanism that is unusual in German. Given these objections, we want to argue for an alternative approach, considering inserted expletives to be an exception to the Case Filter. In other words, we want to make the following generalization:

\section{Inserted expletives do not receive Case.}

Note that this exception only obtains for expletives with unaccusative verbs - as well as in passive constructions. As already observed in the literature, there is evidence that only these expletives are inserted (cf. Herschensohn, 1982; Burzio, 1986; Cardinaletti, 1990). Expletives of impersonal constructions with other than unaccusative (or passive) verbs behave like 'normal' subjects, being base-generated in SpecVP. This can be seen in the following examples where expletive es is never absent, even when the SpecCP contains a lexical element, something that makes our assumption in (47) very natural:

(48) a. Es regnet.

it rains

b. Gestern hat es geregnet. yesterday has it rained

'It rained yesterday.'

c. ${ }^{*}$ Gestern hat geregnet.

yesterday has rained 
(49) a. Es gab viele Überraschungen.

it gave many surprises

'There were many surprises.'

b. Gestern gab es viele Überraschungen.

yesterday gave it many surprises

'Yesterday there were many surprises.'

c. *Gestern gab viele Überraschungen.

yesterday gave many surprises

Unlike expletive es of constructions with unaccusative verbs, the pronoun es in the constructions above, often referred to as a quasi-argument (Chomsky, 1981: 325), is marked for Case and must be assigned a $\theta$-role. As such, therefore, it has to appear in a position where it is able to be assigned Case. Thus, in constructions with a quasi-argumental es the subject position is not available to any NP in need of receiving Nominative Case. In fact, as shown by the following examples, these verbs assign Accusative Case to their objects: ${ }^{12}$

(50) Es regnet Bindfäden.

it rains strings-ACC

'It is raining cats and dogs.'

(51) Es gibt einen neuen Roman von Günther Grass.

it gives a new novel-ACC by Günther Grass

'There is a new novel by Günther Grass.'

These facts are generally explained by the very reasonable assumption that there exist two types of expletives in German, namely those with 'non-argumental' (expletive) use and those with '(fully and quasi-fully) argumental' use (Cardinaletti, 1990). Adopting this distinction, we want to claim further that only argumental expletives must be Case-marked, whereas neither Case nor $\theta$-role ought to be assigned to nonargumental ones, i.e., inserted expletives. ${ }^{13}$

12 It has to be pointed out that in some German varieties, sentences like the following can be observed:

(i) a. Es regnen Steine vom Himmel.

it rain-3pl stones-NOM from-the sky

'It is raining stones from the sky.'

b. Gestern regneten Steine vom Himmel. yesterday rained-3pl stones-NOM from-the sky

'Yesterday it rained stones from the sky.'

These examples indicate that in these varieties the verb regnen 'to rain' functions as an unaccusative verb. This seems to be the case for instance in Spanish, too:

(ii) Ayer llovieron chuzos.

yesterday rained-3pl spears

'Yesterday it rained a lot.'

13 See Hoekstra (1983) and Bennis (1986) for a similiar distinction between there/er and it/het in English and Dutch and Vikner (1995) for a similiar account to expletives in other Germanic languages. Chomsky (1995: 273ff.) also argues for expletives without Case and $\varphi$-features. 
Under the analysis we have proposed, with unaccusative verbs, we attribute the presence of postverbal subjects in German to two factors: first to the fact that expletives in these constructions are inserted in SpecCP without being Case-marked, and second to the verb second property of German which forces the finite verb to move to COMP. Given this, we are able to explain the agreement of unaccusative verbs with postverbal subjects by means of the regular movement of the subject to SpecAgrSP, where it is assigned Nominative under specifier-head agreement.

\subsection{Nominative case without subject verb agreement}

The discussion of unaccusatives in Italian and Spanish, on the one hand, and in German, on the other, has shown that the existence of postverbal subjects in this kind of construction can be explained without weakening the Unaccusative Hypothesis. We have suggested that these NPs receive Nominative Case either by movement to a VP-adjoined position or by movement to SpecAgrSP, that is, to a position in which Nominative assignment ordinarily takes place in these languages. Hence it is not necessary to stipulate any special assignment of Case to the object position.

As for French, however, neither of the two options seems to be adequate. A closer look at the French data makes it apparent that there are indeed some differences with respect to Case assignment to postverbal subjects of unaccusative verbs, since in these constructions we do not find any type of agreement features (cf. Herschensohn, 1982):
a. Il est arrivé beaucoup d'Américains.
it is arrived many of Americans
b. *Il sont arrivés beaucoup d'Américains.
it are arrived many of Americans
'Many Americans arrived,'

In these French examples, movement to SpecAgrSP in order to receive Nominative Case is blocked, because French is not a verb-second language and therefore the standard subject position is filled with the inserted expletive. Thus, we need another answer to the question of how Case is assigned to the postverbal NP in sentences such as (52a).

Before we enter into a more detailed discussion of this question let us have a brief look at a little Romance language, Swiss Rhaeto-Romance. ${ }^{14}$ This language is interesting for our purposes here since it exibits full verb second effects and also has lexical expletives (cf. Spescha, 1989; Haiman and Benincà, 1992). So we should expect that the analysis we have proposed for German unaccusatives also holds in RhaetoRomance.

14 This language, also known as Romansh, is spoken by no more than 50,000 people living near the head waters of the Rhine and along the valley of the Inn in the Swiss canton of Graubinden (Grisons). Dialectal variation is very pronounced. At least five major dialects have been distinguished. The dialect we have chosen for our representation is Surselvan, the major Rhenish dialect (Haiman and Benincà, 1992). 
As far as the clause-initial occurrence of lexical expletives in constructions with unaccusative verbs is concerned, we can observe the same distributional facts as found in German (cf. 44):
a. Igl ei arrivau biars Americans. it is arrived many Americans
b. Biars Americans ein arrivai. many Americans are arrived

However, what is striking is that Rhaeto-Romance behaves exactly like French with respect to agreement. The postverbal NP in (53a) does not agree with the finite verb. This fact is also shown by the ungrammaticality of $(54):{ }^{15}$

(54) ${ }^{*} \mathrm{Igl}$ ein arrivai biars Americans.
it are arrived many Americans

At first glance, this seems to be quite surprising given our analysis for German unaccusatives, namely that the expletive is inserted in SpecCP. One would expect that, Rhaeto-Romance being a verb-second language, it should behave like German in this respect, allowing the postverbal subject to be moved to SpecAgrSP in order to receive Nominative Case under specifier-head agreement. Yet, it seems that this language differs from German with respect to the position where the expletive is inserted. As in French, the expletive appears to be inserted in the standard subject position, SpecAgrSP, thus preventing the movement of the subject NP from its base position to that position.

And indeed, there is strong evidence supporting this assumption. In contrast to Gemian, Rhaeto-Romance allows the presence of a postverbal expletive in unaccusative constructions. In other words, lexical elements other than subject NPs in SpecCP and expletive pronouns are not necessarily in complementary distribution, both sentences in (55) being possible in Rhaeto-Romance (cf. also Haiman and Benincà, 1992: 184; Linder, 1987: 140ff.): ${ }^{16}$

15 Note that the same observations hold for passive constructions:

(i) a. Igl ei vegniu magliau biars meils.

it is become eaten many apples

'Many apples were eaten.'

b. *Igl ein vegni magliai biars meils.

it are become eaten many apples

16 See also Gsell (1984) for similar observations in Dolomitic Ladin, a variety of Rhaeto-Romance spoken in some valleys in the Dolomites.

For reasons which are not very clear to us some informants barely accepted the sentences in (55). Their doubts, though, are not related to the presence of the expletive, since (55a) is equally considered to be odd. At any rate, in passive constructions, the presence of the overt expletive has been accepted by all informants:

(i) a. Ier ei vegniu magliau biars meils. yesterday is become eaten many apples 'Many apples were eaten.' 
(55)
a. Ier ei arrivau biars Americans. yesterday is arrived many Americans
b. Ier eis ei arrivau biars Americans. ${ }^{17}$ yesterday is it arrived many Americans 'Many Americans arrived yesterday.'

These facts clearly indicate that expletives in Rhaeto-Romance unaccusatives are not inserted in SpecCP, otherwise, it would be impossible to explain their occurrence in postverbal position. Hence, it is not an ad hoc assumption to suggest that RhaetoRomance expletives are inserted in SpecAgrSP rather than in SpecCP. It follows then that, whenever an expletive is present, movement to SpecAgrS should be blocked. This assumption is evidenced by the ungrammaticality of sentences like (56):

(56) a. *Igl ei/ein biars Americans arrivau. it is/are many Americans arrived

b. *Ier eis ei biars Americans arrivau. yesterday is it many Americans arrived

The ungrammaticality of these sentences is due to the fact that the subject biars Americans cannot move to the SpecAgrSP position because this position is occupied either by the expletive (cf. 56b) or by the trace left by that expletive in its movement to SpecCP (cf. 56a). Note that the subject NP always agrees with the verb whenever movement to SpecAgrSP has taken place. This is the case in (53b), repeated here as (57), where the subject has moved to SpecAgrSP and then, due to the verb-second constraint, to SpecCP:

\section{[CP Biars Americans $\mathrm{i}_{\mathrm{i}} \operatorname{ein}_{\mathrm{j}}{ }_{\mathrm{IP}} t_{\mathrm{i}} t_{\mathrm{j}}\left[{ }_{\mathrm{VP}}\left[\mathrm{V}^{\prime}\right.\right.$ arrivai $\left.\left.\left.\left.\left.{ }_{\mathrm{NP}} t_{\mathrm{i}}\right]\right]\right]\right]\right]$}

Interestingly, further evidence in favor of this assumption is found in sentences like (58):
a. Ier ein biars Americans arrivai. yesterday are many Americans arrived
b. *Ier ei biars Americans arrivau. yesterday is many Americans arrived 'Many Americans arrived yesterday.'
b. Ier eis ei vegnit magliau biars meils yesterday is it become eaten many apples 'Many apples were eaten.'

17 Note that in postverbal position the Raeto-Romance expletive $i g l$ appears in its allophonic form $e i$, which is in turn homophonous to the 3rd person present form of esser 'to be'. The form eis is an allophonic form of $e i$ 'is', which is used only when it precedes the expletive $e i$. 
In (58a), as in German, the postverbal subject has been moved to SpecAgrSP, i.e., to its standard position whenever an element other than the subject occurs clauseinitially. Note that the presence of the subject in SpecAgrSP results in the agreement patterns which we would predict: Nominative Case is assigned to that position under specifier-head agreement within the AgrS node, i.e., the subject agrees with the verb.

Summarizing our observations on Rhaeto-Romance unaccusatives, we conclude that we are able to account for the agreement patterns in these constructions on the basis of the assumption we also proposed for French that the expletive is inserted in SpecAgrSP. Whenever an expletive is present, agreement is excluded since it prevents subject movement to that position. Note that in Rhaeto-Romance the lack of realization of the lexical expletive does not necessarily imply that the postverbal subject agrees with the verb. This is the case in (55a), and is easily explained by means of our assumption that agreement only occurs if subject and verb are in a specifierhead relation within AgrS. What is peculiar in this case is that the empty placeholder is not necessarily replaced by a lexical expletive as it is the case in the grammar of French.

At this point we arrive again at the question which we postponed when discussing the French data, of how Nominative is assigned to postverbal subjects in French unaccusatives. The same question arises with respect to Rhaeto-Romance. In our opinion, it can be answered if we accept the assumption that both languages allow an operation similar to free inversion in null-subject languages. As already noted, it is generally assumed that free inversion implies the adjunction of the subject NP to the right of VP. In French and Rhaeto-Romance apparently we have the same sort of movement, as can be seen by the fact that the right moved subject must always necessarily appear to the right of the main verb:

(59) a. Il est arrivé beaucoup d'Américains.

b. *Il est beaucoup d'Américains arrivé.

(60) a. Igl ei arrivau biars Americans.

b. *Igl ei biars Americans arrivau.

Note that in French and Rhaeto-Romance the agreement features are determined by the presence of the corresponding expletive, that is, $i l$ and $i g l$ in (59) and (60), where both are singular and masculine. Also, in accordance to our proposal we assume that inserted expletives do not receive Case, therefore since on the one hand Case ought to be discharged, and on the other the postverbal subject needs Nominative Case, we assume that this subject moves to the right, where following Belletti (1988), Raposo and Uriagereka (1990) and Roberts (1993: 24f.), Case is directly assigned to it in the position it occupies:

(61) $\left[{ }_{\mathrm{IP}} \mathrm{Il}\right.$ est $\left[\mathrm{VP}_{\mathrm{VP}}\left[\mathrm{V}_{\mathrm{V}}\right.\right.$, arrivé $\left.\left[{ }_{\mathrm{NP}} t_{\mathrm{i}}\right]\right]$ beaucoup d'Américains $\left.\left.\mathrm{i}\right]\right]$

(62) $\left[\mathrm{CP} \operatorname{Ig}_{\mathrm{k}} \mathrm{ei}_{\mathrm{j}}\left[\mathrm{IP} t_{\mathrm{k}} t_{\mathrm{j}}\left[\mathrm{VP}\left[\mathrm{V}_{\mathrm{v}}\right.\right.\right.\right.$ arrivau $\left.\left[\mathrm{NP}_{\mathrm{i}} t_{\mathrm{i}}\right]\right]$ biars Americans $\left.\left.\left.\mathrm{i}_{\mathrm{i}}\right]\right]\right]$ 
In other words, we propose that the difference between null subject languages on the one hand, and non null subject languages on the other, relies on the fact that in the latter the agreement features are realized by the relationship established between the cxplctive and the finite verb. In null subject languages, on the contrary, we assume that the postverbal subject gets Nominative by means of Case transmission via an empty expletive located in subject position. ${ }^{18}$

\section{Conclusion}

In this article we have shown that the existence of postverbal subject NPs with unaccusative verbs does not represent a problem for the Unaccusative Hypothesis. Quite on the contrary, once the existence of the so-called Partitive Case has been put aside, we have argued that, as predicted by this hypothesis, these NPs have to raise to an appropriate position in order to receive Nominative Case. Thus, we have claimed that the Unaccusative Hypothesis is valid for all contexts with unaccusative verbs and for all the languages discussed. In other words, we are dealing with a rather surface phenomenon which needs to be dealt with by each grammar particularly. ${ }^{19}$

Indeed, we have shown by comparing constructions with unaccusative verbs in several languages that the Case which is assigned to postverbal NPs is always Nominative. In addition, we have argued that languages may differ with respect to the position where Nominative Case is assigned. We have shown that the choice of this position depends on independent factors that differ from language to language. One of these factors is whether the language possesses lexical expletives and the other is the position in which these are inserted, i.e., whether in SpecCP or SpecAgrSP. Among the languages with lexical expletives, the first examined is German where those expletives, according to our proposal, are inserted in SpecCP. The second case is that of French and Rhaeto-Romance, where expletives are inserted in SpecAgrSP. Finally, null subject languages, such as Spanish, Italian and Portuguese, generally lack lexical expletives.

As for agreement facts, we have tried to account for all cases discussed by assuming that subject-verb agreement is related to the fact that Nominative Case is

18 We are aware that this analysis of free inversion is not uncontroversial. In particular, there is some debate about how Case transmission can be formulated theoretically (cf. Safir, 1985; Borer, 1986; Burzio, 1986; Lasnik, 1992). Furthermore, proposals differ concerning the landing site of the postverbal subject (cf. Raposo, 1988; Giorgi and Longobardi, 1991: 171-175; Zubizarreta, 1998).

19 Here, we have to note that there exist some Germanic languages, such as Dutch, that, like RhaetoRomance, allow the postverbal occurrence of overt expletives in unaccusative constructions. The pecularity of these languages, however, is that the postverbal subject agrees with the finite verb, as shown by the following Dutch sentence (cf. Bennis, 1986: 307):

(i) Gisteren zijn er vele Amerikanen aangekomen.

yesterday are it many Americans arrived

In other words, for these languages our approach does not go through, since our prediction for these cases is that agreement between finite verb and postverbal subject should be excluded. We leave open the answer to the question of how to account for these agreement facts. 
assigned under specifier-head agreement: German presents no difficulty since the subject must move to such a position, i.e., SpecIP. The case of Italian, Portuguese and Spanish is explained through the assumption that postverbal subjects are VPadjoined and receive Case from the subject position by transmission through an empty expletive. Finally, French and Swiss Rhaeto-Romance are accounted for, in that Case is directly assigned under government to the VP-adjoined position where postverbal subjects are supposed to land.

\section{References}

Ambar, M.M., 1992. Para uma sintaxe da inversão sujeito-verbo em português. Lisbon: Colibri.

Bayer, J., 1986. Review of: K.J. Safir, Syntactic chains. Studies in Language 10, 167-186.

Belletti, A., 1988. The case of unaccusatives. Linguistic Inquiry 19, 1-34.

Belletti, A. and L. Rizzi, 1981. The syntax of 'ne': Some theoretical implications. The Linguistic Review 1, 117-154.

Bennis, H., 1986. Gaps and dummies. Dordrecht: Foris.

den Besten, H., 1983. On the interaction of root transformations and lexical deletive rules. In: W. Abraham (ed.), On the formal syntax of Westgermania: Papers from the 3rd Groningen Grammar talks, Groningen, January 1981, 47-131. Amsterdam: Benjamins.

den Besten, H., 1985. Some remarks on the ergative hypothesis. In: W. Abraham (ed.), Erklärende Syntax des Deutschen, 53-74. Second revised edition, 1992. Tübingen: Narr. 2.

Borer, H., 1986. I-subjects. Linguistic Inquiry 17, 375-416.

Breckenridge, J., 1975. The post-cyclicity of es-insertion in German. Chicago Linguistic Society 11, 81-91.

Brito, A.M., 1998. Attribution de cas nominatif et ordre des mots dans les constructions impersonnelles en portugais dans une perspective de syntaxe comparée. Ms., Porto.

Burzio, L., 1986. Italian syntax: A government-binding approach. Dordrecht: Reidel.

Calabrese, A., 1992. Some remarks on focus and logical strutures in Italian. Harvard Working Papers in Linguistics 1, 91-127.

Cardinaletti, A., 1990. Es, pro, and sentential arguments in German. Linguistische Berichte 126, $135-164$.

Chomsky, N., 1981. Lectures on government and binding, The Pisa lectures. Second revised edition, 1982. Dordrecht: Foris.

Chomsky, N., 1986. Knowledge of language: Its nature, origin, and use. New York: Praeger.

Chomsky, N., 1995. The minimalist program. Cambridge: MIT Press.

Duarte, Y., 1993. A hipótesc inacusativa e as evidências do português. Revista de documentação de estu dos em lingüística teórica e aplicada 9, 31-58.

Fanselow, G., 1992. 'Ergative' Verben und die Struktur des deutschen Mittelfeldes. In: L. Hoffmann (ed.), Deutsche Syntax: Ansichten und Aussichten, 276-303. Berlin: De Gruyter

Gärtner, H.-M. and M. Steinbach, 1994. Economy, verb second, and the SVO-SOV distinction. Working Papers in Scandinavian Syntax 53, 1-59.

Giorgi, A. and G. Longobardi, 1991. The syntax of noun phrases: Configuration, parameters and empty categories. Cambridge: Cambridge University Press.

Grewendorf, G., 1989. Ergativity in German. Dordrecht: Foris.

Gsell, O., 1984. Unpersönliche Konstruktion und Wortstellung in Dolomitenladinischen. Ladinia 8, 67-98.

Haider, H., 1986. V-second in German. In: H. Haider and M. Prinzhorn (eds.), Verb second phenomena in Germanic languages, 49-75, Dordrecht: Foris.

Haiman, J. and P. Benincà, 1992. The Rhaeto-Romance languages. London: Routledge.

Herschensolnn, J., 1982. The French presentational as a base generated structure. Studies in Language 6, 191-219. 
Herschensohn, J., 1996. Case suspension and binary structure in French. Amsterdam: Benjamins.

Hoekstra, T., 1983. The distribution of sentential complements. In: H. Bennis and W.U.S. van Lessen Kloeke (eds.), Linguistics in the Netherlands, 93-103. Dordrecht: Foris.

Hornstein, N., 1984. Logic as grammar. Cambridge: MIT Press.

Kaiser, G.A., 1998. Verb-Zweit-Effekte in der Romania: Eine diachronische Studie mit besonderer Berücksichtigung des Französischen. Habilitationsschrift, Universität Hamburg.

Laka, I., 1993. Unergatives that assign ergative, unaccusatives that assign accusative. MIT Working Papers in Linguistics 18, 149-172.

Lasnik, H., 1992. Case and expletives: Notes toward a parametric account. Linguistic Inquiry 23, $381-405$.

Le Bidois, R., 1952. L'inversion du sujet dans la prose contemporaine (1900-1950) étudiée plus spécialement dans l'œuvre de Marcel Proust. Paris: d'Artrey.

Lenerz, J., 1985. Zur Theorie des syntaktischen Wandels: Das expletive 'es' in der Geschichte des Deutschen. In: W. Abraham (ed.), Erklärende Syntax des Deutschen, 99-156. Tübingen: Narr.

Levin, B. and M. Rappaport Hovav, 1995. Unaccusativity: At the syntax-lexical interface. Cambridge: The MIT Press.

Linder, K.P., 1987. Grammatische Untersuchungen zur Charakteristik des Rätoromanischen in Graubünden. Tübingen: Narr.

Nascimento, M. do and M.A. Kato, 1995. O estatuto dos nominais pos-verbais dos verbos inaucusativos. Revista de estudos da linguagem 4, 31-74.

Ortiz de Urbina, J., 1989. Parameters in the grammar of Basque: A GB approach to Basque syntax. Dordrecht: Foris.

Perlmutter, D.M., 1978. Impersonal passives and the unaccusative hypothesis. Berkeley Linguistics Society $4,157-189$.

Platzack, C. and A. Holmberg, 1989. The role of Agr and finiteness in Germanic VO languages. Working Papers in Scandinavian Syntax 43, 51-76.

Pollock, J.-Y., 1983. Accord, chaînes impersonnelles et variables. Lingvisticae Investigationes 7 , 131-181.

Raposo, E., 1988. Romance inversion, the minimality condition and the ECP. In: Proceedings of the 18th meeting of the North East Linguistic Society, 357-374. Amherst: The University of Amherst.

Raposo, E. and J. Uriagereka, 1990. Long-distance case assignment. Linguistic Inquiry 21, 505-537. de Rijk, R., 1972. Partitive assignment in Basque. Anuario del Seminario de Filología Vasca 'Julio de Urquijo' 6, 130-173.

Rizzi, L., 1982. Issues in Italian syntax. Dordrecht: Foris.

Roberts, I., 1993. Verbs and diachronic syntax: A comparative history of English and French. Dordrecht: Kluwer.

Safir, K.J., 1985. Syntactic chains. Cambridge: Cambridge University Press.

Schwartz, B.D. and S. Vikner, 1996. The verb always leaves IP in V2 clauses. In: A. Belletti and L. Rizzi (cds.), Parameters and functional heads: Essays in comparative syntax, 11-62. New York: Oxford University Press.

Spescha, A., 1989. Grammatica sursilvana. Cuera: Casa editura per mieds d'instrucziun.

Tomaselli, A., 1986. Das unpersönliche es: Eine Analyse im Rahmen der Generativen Grammatik. Linguistische Berichte 102, 171-190.

Torrego, E., 1984. On inversion in Spanish and some of its effects. Lingustic Inquiry 15, 103-129.

Vikner, S., 1995. Verb movement and expletive subjects in the Germanic languages. New York: Oxford University Press.

Wunderlich, D., 1985. Über die Argumente des Verbs. Linguistische Berichte 97, 183-227.

Zubizarreta, M.L., 1998. Prosody, focus and word order. Cambridge: The MIT Press. 